\title{
EFFECT OF ANTIFUNGAL TREFLAN AND LENTIL ESSENTIAL OIL DISC INHIBITION METHODS ON LAGENIDIUM CALLINECTES
}

\author{
Marcellia Selvi ${ }^{1}$, Saputra Afandi ${ }^{2 \star}$, Ulfa Ade Maria ${ }^{1}$ \\ ${ }^{1}$ Department of Pharmacy, Faculty of Medicine, University of Mahalayati, \\ Lampung, Indonesia \\ ${ }^{2}$ Department of Aquaculture, Sekolah Tinggi Perikanan Jakarta, Indonesia \\ ${ }^{\star}$ E-mail: afandi.saputra@yahoo.co.id
}

\begin{abstract}
Lagenidium callinectes is marine phycomycetous parasitic fungus capable to spread disease in marine Crustacea eggs and larvae. Treflan (trifluralin, Elanco) is used in penaeid shrimp larval mycosis treatment. The disease was caused by the phycomycetous fungi Lagenidium sp. and Sirolpidium sp. The study aimed to determine the efficacy of Treflan and Lentil Essential Oil to Lagenidium callinectes growth inhibition in Potatoes Dextrose Agar (PDA) + $2 \% \mathrm{NaCl}$. This study was observational analytical research utilizing experimental design. The data were obtained from two treatment group. Treatment Group 1 used Lentil Essential Oil and Treatment Group 2 used Treflan product. Each treatment dilution $10^{-1}, 10^{-2}, 10^{-3}, 10^{-4}$, $10^{-5}, 10^{-6}$ were dripped onto disc. The control group was immersed in sterile seawater. The inhibition zone diameters from each plate were measured. The treflan treatment group exhibited Lagenidium sp. $11.08 \mathrm{~cm}$ growth inhibition zone in the second day of incubation and $8.27 \mathrm{~cm}$ growth inhibition zone in the third day of incubation on dilution $10^{-1}(100.000$ ppm). Lentil Essential Oil treatment group exhibited Lagenidium $\mathrm{sp} 8.38 \mathrm{~cm}$ growth inhibition zone on the second day of incubation on dilution $10^{-1}(100000 \mathrm{ppm})$. The study indicated that Treflan and Lentil Essential Oils are capable to inhibit Lagenidium sp. growth as these contain antifungal compounds.
\end{abstract}

\section{KEY WORDS}

Lagenidium sp., Treflan product, lentil essential oil, growth inhibition.

Lagenidium callinectes is a marine phycomycetous parasitic fungus. Lagenidium callinectes or similar species have been reported spread disease on marine Crustacea eggs and larvae. The Lagenidium exhibits similar pathology in all host species. In wild crustacean populations, it affects the eggs. In aquaculture, however, it affects both eggs and larvae [1].

Lagenidium callinectes hyphae forms are contorted, irregularly branched, sparingly septate. It possesses cell wall and membrane, vacuoles, mitochondria, ribosomes, small and large vesicles, and woronin bodies. Lagenidium callinectes spore is singular or in pairs. The fungal Mycelium could either invade or infect larval Penaeus monodon muscle tissues [2].

Treflan (trifluralin, Elanco) is used in penaeid shrimp larval mycosis treatment. The disease was caused by the phycomycetous fungi Lagenidium sp. and Sirolpidium sp. Some culturists have reported treatments using Mfluralin to be ineffective while others have found it to be quite efficacious [3].

Lentil Essential Oil (LEO) contains sweet almond oil, lavender oil, coconut oil, olive oil, peppermint oil extract. These extracts are used as antifungal and antibacterial.

The specific objectives of this study were to determine the efficacy of LEO and Treflan product to inhibit pathogenic fungus growth in agar media.

\section{MATERIALS AND METHODS OF RESEARCH}

The fungus was obtained from AHS Lab. These samples were identified, purified, certificated, and assessed by a Professor. Other materials used were Lentil Essential Oil. Treflan Product, PDA medium, Incubator, Petri dish. 
Agar media used in this experiment was PDA+2\% $\mathrm{NaCl}$. Agar media was kept in $4^{\circ} \mathrm{C}$ temperature prior to the experiment.

Pure fungus isolate was obtained from PDA agar, which was procured from AHS Lab. Fungus culture used were 5-7 days old. The fungal colony was suspended in $50 \mathrm{ml}$ of sterile seawater $20 \mathrm{ppt}$ in a beaker and incubated at $30^{\circ} \mathrm{C}$ for $48 \mathrm{~h}$ to induce zoospore formation. Zoospore densities were estimated using hemocytometer light microscopy [4]. After determining zoospore densities, based on the modification of the method by Tidaporn, Spores was transferred to agar media (SDA+2\% NaCl+ $100 \mathrm{mg}$ gentamicin) [5]. Treatment Group 1 used 15 ul Lentil Essential Oil dilutions $10^{-1}, 10^{-2}, 10^{-3}, 10^{-4}, 10^{-5}, 10^{-6}$. The dilution was dripped onto a disc and was incubated at $25-27^{\circ} \mathrm{C}$. Treatment Group 2 would be used 15 ul Treflan product dilution $10^{-1}, 10^{-2}, 10^{-3}, 10^{-4}, 10^{-5}, 10^{-6}$. The dilution was dripped onto a disc and incubated at $25-27^{\circ} \mathrm{C}$. The control group used sterile seawater. After 24 hours of incubation, the inhibition zone diameters from each plate were measured.

Table 1 - Experimental Design

\begin{tabular}{|c|c|c|c|c|}
\hline Location & Group & Rep & Dilution & Product \\
\hline Lab Fungus & Treatment (Disc) & 3 & $\begin{array}{l}10^{-1} \\
10^{-2} \\
10^{-3} \\
10^{-4} \\
10^{-5} \\
10^{-6} \\
\end{array}$ & Lentil Essential Oil \\
\hline Lab Fungus & Treatment (Disc) & 3 & $\begin{array}{l}10^{-1} \\
10^{-2} \\
10^{-3} \\
10^{-4} \\
10^{-5} \\
10^{-6}\end{array}$ & Treflan \\
\hline Lab Fungus & Control & 3 & $20 \mathrm{ppt}$ & Sterile sea water \\
\hline
\end{tabular}

The Fungi growth Inhibition Test was conducted at Integrated Laboratory in June 2016.

\section{RESULTS OF STUDY}

Table 1 exhibits the efficacy of each Lentil Essential Oil and Treflan product on Lagenidium sp. Lentil Essential Oil and Treflan at $10^{-1}$ dilution inhibited the growth of Lagenidium sp.

Table 1 - The efficacy of the Lentil Essential Oil and Treflan Product on the fungi growth inhibition and minimum inhibitory concentration (MIC)

\begin{tabular}{ccccc}
\hline \multirow{2}{*}{ Treatment } & \multicolumn{3}{c}{ Lagenidium sp. Growth Inhibition } & \multirow{2}{*}{ MIC } \\
\cline { 2 - 4 } & DOI 2 & DOI 3 & DOI 4 & \\
\hline Treflan & $11,08 \pm 1,04$ & $8,27 \pm 0,10$ & $0,00 \pm 0,00$ & $10^{-1}$ \\
\hline Lentil Essential Oil & $8,38 \pm 0,13$ & $0,00 \pm 0,00$ & $0,00 \pm 0,00$ & $10^{-1}$ \\
\hline Sea Water (control) & $0,00 \pm 0,00$ & $0,00 \pm 0,00$ & $0,00 \pm 0,00$ & \\
\hline
\end{tabular}

NB: DOI (Day of Incubation) Average $\pm S D$.

\section{DISCUSSION OF RESULTS}

Lagenidium sp. is parasite species in arthropods class, known to attack L. Vannamei shrimps. A fungal disease caused by $L$. callinectes was reported from larval $P$. monodon from India for the first time. The morphology of the hyphae and spores described in the study is very similar to the description of the fungus in $P$. Setiferus [6].

Lagenidium sp growth was assessed using Treflan. It exhibited $11.08 \mathrm{~cm}$ inhibition zone on the second day of incubation and $8.27 \mathrm{~cm}$ inhibition zone in the third day of incubation. This occurred on dilution $10^{-1}(100.000 \mathrm{ppm})$ (Figures 1-2). Treflan contains trifluralin (dinitroaniline) or organic herbicide. Dinitroaniline herbicide would be active when 
applied the growing media before the fungal hyphae grew. Dinitroaniline herbicide worked as mitotic toxic that inhibits the fungal hyphae growth.

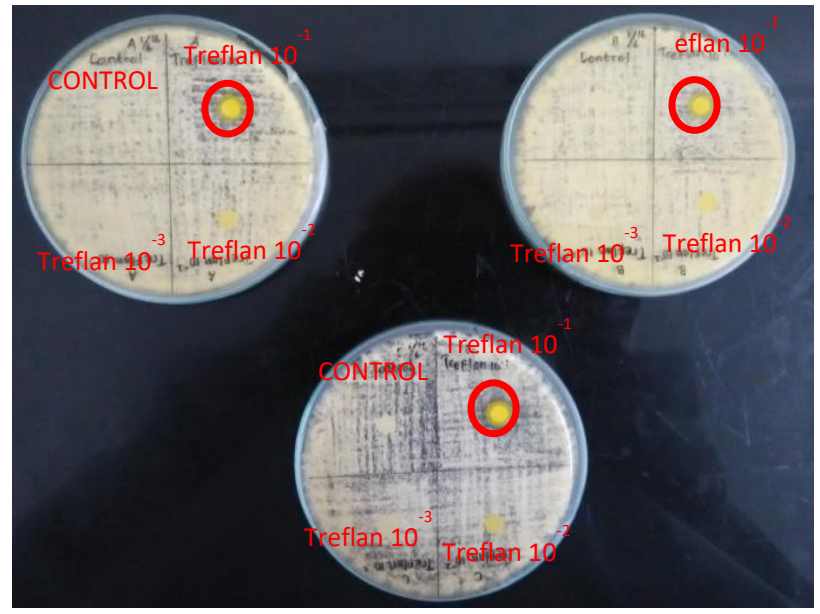

Figure 1 - Inhibition zone in Treflan group on the second day of incubation (1A) Treflan Replicate A; (1B) Treflan Replicate B; (1C) Treflan Replicate C

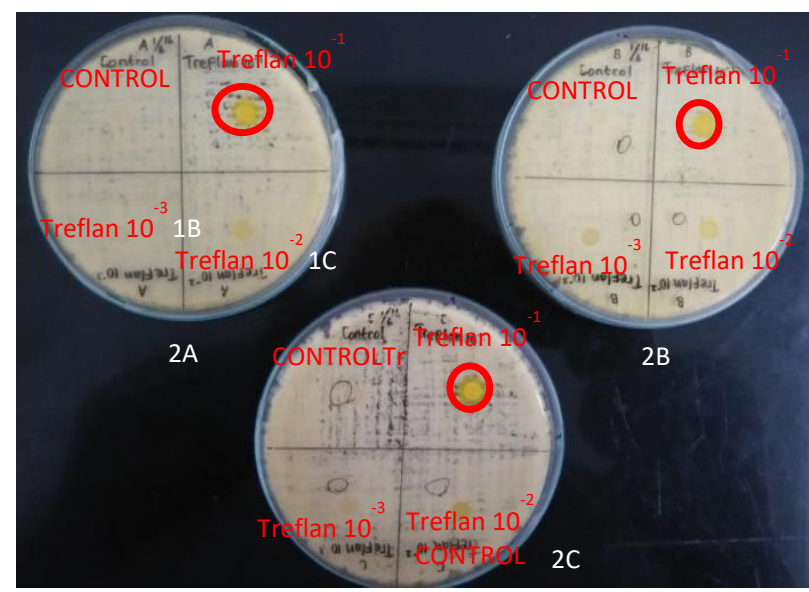

Figure 2 - Inhibition zone of Treflan group on the third day of incubation (2A) Treflan Replicate A; (2B) Treflan Replicate B; (2C) Treflan Replicate C

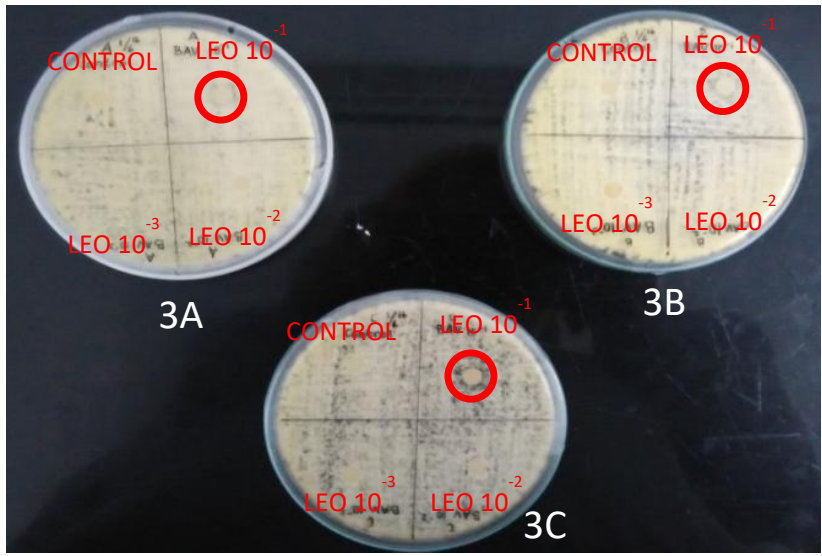

Figure 3 - Inhibition zone in Lentil Essential Oil (LEO) group on the second day of incubation (3A) Lentil Essential Oil Replicate A; (3B) Lentil Essential Oil Replicate B; (3C) Lentil Essential Oil Replicate C 
Treflan products reduced damage caused by Lagenidium $s p[2,7,8]$. Some culturists have reported trifluralin to be efficacious while others have found it to be ineffective. At the E.R.L.-Marine Culture Facility at Kahuku, Oahu, Hawaii, periodic treatments with trifluralin were less effective compared to a continuous drip system. $0,5 \mathrm{ppm}$ Treflan treatment inhibited Lagenidium growth and spread. It reduced the mortality rate of the infected $P$. monodon larval compared to the less effective $0,1 \mathrm{ppm}$ Treflan treatment $[9,10]$. In a previous study, Baticados recommended a $20 \mathrm{ppm}$ Treflan treatment for 2 hours. Boonyaratpalin recommended a daily treatment of $0,01-0,05 \mathrm{ppm}$ of Treflan [11,12]. Treflan treatment should be at 10 ppb every $4 \mathrm{~h}$ to contain Lagenidium infections [13].

Lentil Essential Oil assessment on Lagenidium exhibited $8.38 \mathrm{~cm}$ inhibition zone on the second day of incubation on dilution $10^{-1}$ (100000 ppm). Lentil Essential Oil contains sweet almond oil, lavender oil, coconut oil, olive oil, peppermint oil which functions as antifungal and antimicrobial.

Treflan product and Lentil Essential Oil assessment Lagenidium sp. growth exhibited that treflan product is more effective. The Treflan product produces an inhibition zone up to the third day of incubation. On the other hand, Lentil Essential Oil product exhibited an inhibition zone up to the second day of incubation.

\section{CONCLUSION}

The study exhibited that Treflan and Lentil Essential Oils are capable to inhibit Lagenidium sp growth. Both Treflan and Lentil Essential Oils contain antifungal compounds. Treflan product contains Trifluralin. Lentil Essential Oil contains extraction of sweet almond oil, lavender oil, coconut oil, olive oil, peppermint oil. These are especially effective to inhibit fungal hyphae growth.

\section{REFERENCES}

1. Couch, J. N. 1942. A new fungus on crab eggs. J. Elisha Mitchell Sci. Soc.58: 158-162.

2. Ramasamy, P., Rajan, P. R., Jayakumar, R., Rani, S., Brennan, G. P. 1996. Lagenidium callinectes infection and its control in cultured larval Indian tiger prawn, Penaeus monodon Fabricius. Journal of Fish Disease Vol. 19:1.

3. Bland, C. E. 1975. Fungal diseases of marine crustacea. Pages 41-48 in Proceedings of the Third U.S.-Japan Meeting on Aquaculture at Tokyo, Japan, October 15-16. 1974. Fishery Agency, Japanese Government and Japan Sea Regional Fisheries Research Laboratory.

4. Krishnika, A. and Ramasamy, P. 2014. Lagenidium sp infection in the larval stages of the freshwater prawn Macrobrachium rosenbergii (De Man). Indian Journal of Fisheries 61(2):90-96.

5. Tidaporn C., B. Muenthaisong, S. Chaweepack, and K. Kamei. 2015. The Potential of Galangal (Alpinia galanga Linn.) Extract against the Pathogens That Cause White feces Syndrome and Acute Hepatopancreatic Necrosis Disease (AHPND) in Pacific White Shrimp (Litopenaeus vannamei). Int. Journal of Biology 7(3), 16-71.

6. Lightner D.V. \& Fontaine C.T. 1973. A new fungus disease of the white shrimp Penaeus setiferus. Journal of Invertebrate Pathology 11, 94-9.

7. Aquacop. 1977. Observations on diseases of crustacean cultures in Polynesia. Pages 685-703 in J. W. Avault, Jr., editor. Proceedings of the Eighth Annual Meeting, World Mariculture Society. Louisiana State University, Baton Rouge, Louisiana, USA.

8. Lio-Po, M. E., E. C. Sanvictores, M. V. L. Baticados, and C. R. Lavilla. 1982. In vitro effect of fungicides on hyphal growth and sporogenesis of Lagenidium spp. isolates from Penam monodon and Scylla serrata eggs. Journal of Fish Diseases 5, 97-112.

9. Chen D. 1992. An overview of the disease situation, diagnostic techniques, treatments and preventives used on shrimp farms in China. In: Diseases of Cultured Penaeid Shrimp in Asia and the United States (ed. by W. Fulks \& K.L. Main), pp. 47-55. Oceanic Institute, Honolulu, HI. 
10. Kazuyo N., S. Wada, K. Hatai, and T. Sugimoto. 1994. Lagenidium myophilum infection in the coonstripe shrimp, Pandalus hypsinotus. Mycoscience 35, 99-104.

11. Baticados M.C.I. 1988. Diseases of prawns in the Philippines. SEAFDEC Asian Agriculture 101, 1-8.

12. Boonyaratpalin S. 1990. Shrimp larval diseases. In: Technical and Economic Aspects of shrimp Fanning (ed. by M.B. New, (H. deSaram \&Tbarlochan Sing), pp. 158-163. Proceedings of the AQUATECH Conference 90. Kuala Lumpur, Malaysia.

13. Flegel, T.W., Fegan, D.F., Kongsom, S., Vuthikomudomkit, S., Sriurairatana, S., Boonyaratpalin, S., Chantanachookhin, C., Vickers, J.E., Macdonald, O.D., 1992. Occurrence, diagnosis, and treatment of shrimp diseases in Thailand. In: Fulks, W., Main, K.L. Eds., Diseases of Cultured Penaeid Shrimp in Asia and the United States. The Oceanic Institute, Hawaii, pp. 57-112. 